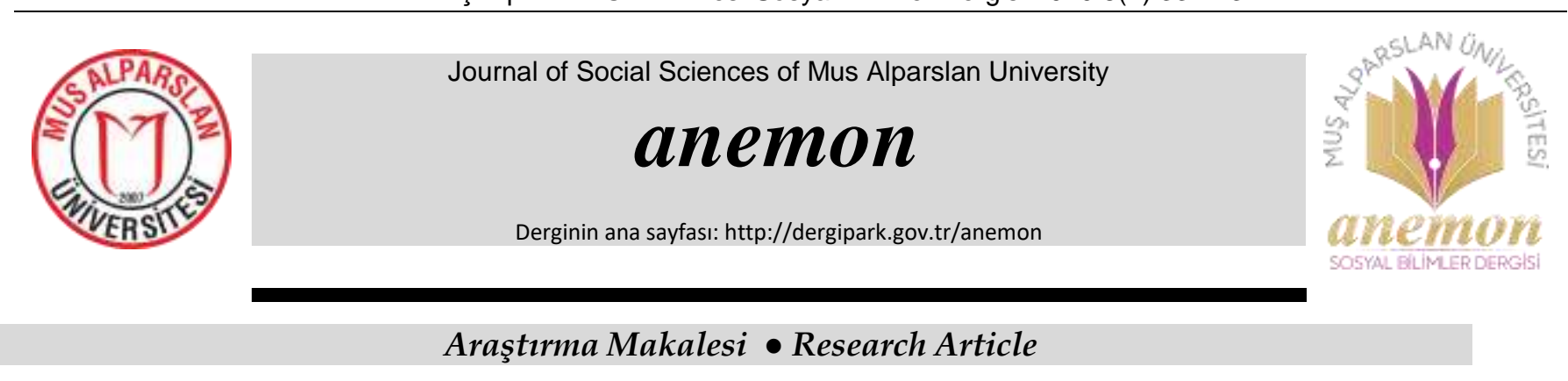

\title{
XVIII. Yüzyılda Avusturya’da Alla-Turca Anlayışı ve Buna Etki Eden Unsurlar
}

\section{The Perception Of Alla-Turca In Austria In The 18th Century and Its Impacted Elements}

Emrah İstek ${ }^{\mathrm{a}, *}$

a Dr. Öğr. Üyesi, Ağrı İbrahim Çeçen Üniversitesi, Fen Edebiyat Fakültesi, Tarih Bölümü, Yeniçağ ABD, Ağrı/Türkiye. ORCID: https://orcid.org/0000-0003-1407-3609

\section{MAKALE BİLGİSI}

Makale Geçmişi:

Başvuru tarihi: 01 Şubat 2019

Düzeltme tarihi: 21 Eylül 2019

Kabul tarihi: 04 Ekim 2019

\author{
Anahtar Kelimeler: \\ Alla-Turca \\ Türkenmode \\ Osmanlı Devleti \\ Avusturya \\ XVIII. Yüzyıl
}

\section{ARTICLE INFO}

\section{Article history:}

Received 01 February 2019

Received in revised form 21 September 2019

Accepted 04 October 2019

\section{Keywords: \\ Alla-Turca \\ Turkish Fashion \\ Ottoman Empire \\ Austria \\ 18th Century}

\section{ÖZ}

Osmanlı Devleti ile Avusturya'nın birbiri ile teması XVI. yüzyılda başlasa da, XVIII. yüzyıla kadar kültürel anlamda ciddi bir etkileşimden bahsedilemez. XVIII. yüzyılda ise her iki ülkenin birbiriyle antlaşma zemini arama çabası, Osmanlı Devleti'nin Avrupa'ya geçici elçiler göndermesi; Avusturya'da Türklerle ilişkilerin artırılması için Şark Akademisinin kurulması ve Türk modasının ülke içerisinde yayılmaya başlaması gibi etkenler karşlıklı etkileşimi artırmıştır. XVIII. yüzyıl başlarından sonuna kadar Avusturya'da Türk usulüne uygun veya da Alla-Turca anlayışına özgü yapılan düğünler, resmigeçitler ve merasimler, yiyecek, içecek ve giyecek anlayışı ile mimari yapılar, müzik aletleri ve müzikaller, Türk modasının Avusturya'daki hâkimiyetini göstermesi açısından önemlidir. Bu nedenle bu çalışmada Avusturya'daki Alla-Turca akımı örneklerle gösterilmeye çalışılmış ve araştırmayı somut verilere dayandırmak amacıyla XVIII. yüzyıla ait görseller çalışmanın sonuna eklenmiştir.

\section{A B S T R AC T}

The contact between the Ottoman Empire and Austria XVI. century, XVIII. Century until a serious cultural interaction can not be mentioned. In the 18th century, both countries tried to seek a treaty ground with each other, the Ottoman Empire sent temporary envoys to Europe; In order to increase relations with Turks in Austria, factors such as the establishment of the Orient Academy and the spread of Turkish fashion in the country have increased the interaction. From the beginning of the 18th century until the end of this period, weddings, parades and ceremonies food, beverage and clothing culture, architectural structures, musical instruments and musicals made in Austria according to Turkish duly or Alla-Turca concept are important for demonstrating the dominance of Turkish fashion in Austria. Therefore, this study was tried to illustrate the Alla-Turca flow in Austria and was added to the end of the 18th century study to base the research on concrete data.

\section{Giriş}

Mohaç Meydan Muharebesi (1526) sonrası karşı karşıya gelen Avusturya ve Osmanlı Devleti, XVIII. yüzyılın sonlarına kadar yoğun bir mücadele içinde olmuştur. $\mathrm{Bu}$ zaman zarfinda her iki devlet arasında yaşanan siyasi ve askeri gelişmeler, söz konusu devletlerarasında bir kültür transferini de beraberinde getirmiştir. Özellikle XVI. yüzyılın ikinci yarısında Avusturya'da "Erbfeind (Ezeli Düşman)" (Mayr, 1607, s. 2) olarak tasvir edilen Osmanlı Devleti, yazılı ve görsel yayınların da etkisiyle bütün imparatorluk coğrafyasında kötülüğün kaynağı olarak gösterilmiştir. Türklere karşı düşmanlığı artırıcı yazılı ve görsel aktarımlar, aynı zamanda yöneticilerin kendi nüfuzlarını artırmak için de bir malzeme olarak kullanılmıştır.

XVII. ve XVIII. yüzyıllar önceki yüzyıllardan çok da farklı olmamış, basit mevzuların dahi çarpıtılarak aktarılmasına, önyargıların ve korkuların görsel içeriklerle güçlendirilmesine devam edilmiş, ancak bunlar geçmiş yıllara oranla nicelik bakımından daha az sayıda olmuştur. Nitekim yüzyıllar boyunca birbirine düşman olan bu iki devlet arasında XVIII. yüzyıldan itibaren kültürel

\footnotetext{
* Sorumlu yazar/Corresponding author.

e-posta: eistek@agri.edu.tr
} 
benzeşmelerin arttığı görülmektedir. Tesadüfi olamayacak bu durumun ardında elbette ki bazı sebepler bulunmaktadır. Öncelikli olarak, II. Viyana kuşatmasıyla beraber Osmanlı Devleti'nin Avrupa'daki etkinliğinin zayıflamaya başlaması, hemen sonrasında yaşanan Selankamen ve Zenta Savaşları ve nihayetinde imzalanan Karlofça Antlaşması Osmanlı'nın Avusturya nezdindeki prestijini düşürmüştür. Bunların yanı sıra Rusya ve Venedik'e karşı kazanılan başarılara rağmen, Avusturya ile yapılan Petervaradin Savaşı ve akabinde imzalanan Pasarofça Antlaşması (1718) Osmanlı Devleti'ni Balkanlara çekilmek zorunda bırakmıştır. XVIII. yüzyılın ortalarına doğru ise Avusturya'da yaşanan bazı hadiseler iki devlet arasındaki ilişkilerin mevcut antlaşmaların uzatılmasıyla devam etmesine neden olmuştur. Zira RomaGermen İmparatoru VI. Karl, erkek bir varis bırakamadığından, tahtını kızı Maria Theresia’ya bırakmış ve yeni imparatoriçe de Osmanlı ile savaşmaktan ziyade merkezi otoritesini güçlendirmek ve tahtını sağlamlaştırmak için Prusya ile savaşmak mecburiyetinde kalmıştır. Maria Theresia'nın ölümüne kadar yaşanan barış dönemi, XVIII. yüzyılın sonlarında Theresia'nın oğlu II. Joseph'in Rusya yanlısı bir politika izlemesi nedeniyle sona ermiş ve iki devlet arasında son kez gerçekleşecek olan bir savaş daha yaşanmıştır. Söz konusu bu savaş II. Leopold döneminde imzalanan Ziştovi Antlaşması (1791) ile sona ermiştir. (Koçak, 2018, s. 280)

Savaşlar sonrasında imzalanan antlaşma metinlerini ve taht değişikliği haberlerini götüren veya devlet yöneticilerinin emriyle herhangi bir sebepten ötürü yollanan elçiler, mal getirip götüren tüccarlar ve seyyahlar devletler arasındaki kültür etkileşiminde önemli roller üstlenmişlerdir. Söz konusu durum Osmanlı Avusturya arasındaki faaliyetler için de geçerlidir. TTüccarların getirdiği Türk malları kısa zamanda Avusturya'da kendine bir pazar bulmuş ve Türklerin kullandığı silahlar, giydikleri kıyafetler, k1yafetlerin dikildiği kumaşlar, enstrümanlar ve hatta porselen Türk eşyaları dahi aranan ürünler arasında olmuştur. Bunun yanı sıra Avusturya sarayı da Alla-Turca veya da Türk modası olarak adlandırılan bu akımdan etkilenmiş, resmigeçit törenlerinde, evlilik merasimlerinde ve sarayda yapılan özel balolarda zevk ve gösteriş unsuru olarak kullanılması hususu açıkça görülmüştür. Bunun yanı sıra Türklere veya Türk kültürüne ait bazı eşyaların zevk ü sefa dışında Türk düşmanlığını artırmak için de kullanıldığını göz önünde bulundurmak gerekmektedir. Nitekim Veziriazam Kara Mustafa Paşa'nın II. Viyana Kuşatmasındaki mağlubiyeti bir sikke üzerine bastırılmış ve sikkede vezirin kavuğunun Avusturya'nın simgesi olan çift başlı kartal tarafından alınması mizahi bir şekilde yansitılmıştır. (Resim 1)

\section{XVIII. Yüzyılda Avusturya'da Alla-Turca}

XVIII. yüzyıl Almanca kaynaklarda Osmanlı Devleti, doğrudan Türk devleti olarak algılandığından, Türklere/Osmanlı'ya özgü olan eşya, kıyafet, yiyecek, silah, ev tekstili ve hatta eğlence şekli "Alla Turca" veya da “Türkischer Art (Türk tarzı)" olarak adlandırılmıştır.

Alla Turca kapsamında değerlendirilen maddelerin başında Türk kahvesi, ayçöreği gibi yiyecekleri; halı ve sembolik dekorasyon malzemeleri (lale, hilal vs.) gibi ev eşyalarını, doğuya özgü kıyafetler gibi görsel eşyaları ve ayrıca düğün, harem ve oyun gibi kültürel değerleri saymak mümkündür.
Osmanlı Devleti'nin baharat, çay ve kahve gibi lüks sayılacak ihtiyaçların transfer ülkesi olması, Batı dünyasının Doğu'yu, Osmanlı Devleti üzerinden okumasını zorunlu kılmıştır. Bunlara ek olarak harem hayatı ve “Orient(Doğu)"e has kültürel ve sosyal olgular, Osmanlı ile sınırdaş olan Avusturya'da "Türk" topraklarına olan ilgiyi artırmıştır. $\mathrm{Bu}$ ilginin artmasında Alman topraklarından gelen seyyahların da önemli bir rol oynadığını belirtmek gerekmektedir. Zira Osmanlı Devleti'nin savaşların dışında kendini Batıya tanıtması, ancak XVIII. yüzyılda elçilerini daha sık ve uzun süreli olarak Avrupa'ya yollamasıyla mümkün olmuştur. Bununla birlikte Osmanlı Devleti XVIII. yüzyıla kadar özellikle yabancı devletlerle olan diplomatik ilişkilerini, o devletin elçisiyle İstanbul'da görüşmek suretiyle çözme yoluna gitmiştir. Bu durum ise elçilerin Osmanlı ile ilgili edindikleri izlenimleri ülkelerine döndüklerinde, abartılı ve sübjektif bir surette ülkesinin yöneticilerine ve kaleme aldıkları seyahatnamelerle de halka aktarmasına sebep olmuştur. Ancak, XVIII.yüzyılda Osmanlı Devleti'nin Paris, Berlin ve Viyana gibi Avrupa başkentlerine -süreli de olsa- elçiler göndermesi, müreffeh ve zengin Doğu'nun yakından tanınmasına neden olmuştur. $\mathrm{Bu}$ elçilerin görev yapacakları şehre oldukça gösterişli törenlerle girmesi, bazı balolardaki kibar davranışları ve cömert hediyeleri Türklere karşı bir yakınlık hissinin uyanmasını sağlamıştır. Türklerin bu davranışları uzaktaki bilinmeyen "Barbar Türk imaj1” yerine, gözle görülen "onlar gibi bir insan olan Türk" ü temsil anlamına gelmekteydi. Onun içindir ki her gelen elçi halk tarafindan merakla izlenmiştir. Örneğin 1719 yılında Avusturya'da bulunan elçi İbrahim Paşa'nın her hareketinin dönemin basını tarafından gözlemlendiği görülmektedir. Hatta kurban bayramındaki kurban kesimi ve diğer İslami ritüeller yadırganmadan gazetede detaylarıyla yer bulmuştur. (Wienerisches Diarum, 25 Ekim 1719, s. 2) İmparator ve eşinin Türk elçiye olan merakı aslında Avusturya halkının duygularının bir yansıması gibidir. Zira İbrahim Paşa'nın gelişinden endişe ile karışık merak duygusu imparatorun ve eşinin tebdili kıyafet ile halkın içine karışmasına ve buradan da sefirin Viyana'ya görkemli girişini ve mola yerlerindeki davranışlarını takip etmesine neden olmuştur. Ayrıca 1748 yılında Viyana'ya giden Mustafa Hatti Efendi’nin gösterişli heyeti, Viyanalıların sokaklara dökülmesine sebep olmuştur. (Savaş A. İ., 1991, s. 237) Ancak söz konusu yüzyılda Avrupa saraylarında görülen Türk modasının Osmanlı Devleti ve Türklere beslenen hayranlıktan ziyade, lüks ve oryantal yaşamın verdiği mistik coşkudan kaynaklandığını da ayrıca belirtmek gerekir.

Fransa'dan başlayarak tüm Avrupa'yı etkisi altına alan Türk modasının Avusturya'yı da etkilediği bilinmektedir.(Kruschkova \& Lipp, 2004, s. 77) Zira bu dönemde Maria Theresia ve Şansölye Kaunitz Prusya'ya karşı bir müttefik arayışına girmiş ve bu nedenle Fransa ile yakın ilişkiler kurmuştur. İki ülke arasındaki bu yakınlık, Avusturya prensesi Maria Antoinette ile Fransa veliahdının evlendirilmesi ile daha da pekişmiş ve bu durum kültür transferini ve beraberinde Alla-Turca anlayışının Avusturya'ya girmesine neden olmuştur. Avusturya'daki Alla-Turca anlayışı kendisini en belirgin olarak 1723-1739 yılları arasında bir camii mimarisiyle inşa edilen ve günümüzde de kilise olarak kullanılan "Wiener Karlskirche" adlı yapıda göstermektedir (Resim 2). (Richter, 2008, s. 121) Avusturya'nın düşmanı durumunda olan Prusya da Türk 
modasında etkilenme hususunda diğer Avrupa ülkelerinden geri kalmamıştır. 1773 yılında Schweitzingen Sarayı'nın bahçesine bir camii mimarisi şeklinde inşa edilen ve günümüzde de "Die Schwetzinger Moschee" olarak isimlendirilen bu yapıda İslâm'ı ve Osmanlıyı temsil eden hilaller ve hatta duvarlar üzerine yazılmış Kuran'dan ayetler bulunmaktadir. (Richter, Die Schweitzinger Moschee-ein Tempel der Weltweisheit?, 2008, s. 115) (Resim 3)

Avrupa'daki Türk modası, Avusturya coğrafyasındaki balolar veya resmi toplantılarda da kendini göstermeye başlamıştır. Öncelikle Türklerin akınlarıyla doğrudan karşılaşmayan ve ülkenin kuzey ve batı tarafinda bulunan Saksonya bölgesi gibi eyaletlerde Türk modasının daha da çok takip edildiği görülmektedir. Bunun en çarpıcı örneği Saksonya prensi II. Friedrich August ile Avusturya Arşidüşesi Maria Josepha'nın düğünündeki konsepttir. Ağustos 1719 tarihinde Viyana'da, 17 Eylül 1719 tarihinde ise Dresden şehrinde gerçekleşen ve yaklaşık olarak 4 Milyon Taler harcanan bu düğün, 4 hafta sürmüştür. Dügün hazırlıkları öncelikle şehrin doğu tarafindan bulunan Elbe* kıyılarındaki çayırlara Türk çadırları kurulmasıyla başlanmış ve hem çadırlar hem de dekorasyonda kullanılan kumaşlar, egzotik doğu usullerine göre süslenmiş ve birçok hilal motifi de kullanılmıştır. Merasim yeniçeri kostümü giymiş kişilerin şenlik ateşini elinde tutarak içeri girmesiyle başlamıştır. Damat, Türk zırhı ve başlığı takarak bir tuğ ile Türk kıyafetleri giyen dört kişi eşliğinde düğün alanına gelmiş, gelin ve damat Türk çadırı şeklinde tasarlanmış masaya oturtulmuş, (Mikosch, 1995, s. 236) davete katılan misafirlerin de Türk kiyafetleri giymesi mecburi tutulmuştur. (Rexheuser, 2015, s. 229; Schuckelt, 2010, s. $247 v d)$ Düğün alayının şehre girmesi de yine Türk usullerine göre yapılmış ve Osmanlı sarayında olduğu üzere 24 at; Türk eğeri, dizgini ve eğer örtüsü ile süslenmiş, gelin arabasını süren siyah tenli birisine de, sarı atlas kumaştan giysi giydirilmiş, başına Türk başlığı takılmış ve silah olarak da Türk gürzü taşıması emredilmiştir. Arabanın arkasında ise Türk kıyafeti giydirilmiş 24 siyah tenli insan altışarlı sıra halinde dizilmiş ve ellerine de çift taraflı Osmanlı baltası verilmiştir. (Resim 4) (Mikosch, 1995, s. 236) Ayrıca düğünde bir şair tarafından yeni evli çiftlere yine Türk temalı bir şiir seslendirilmiştir. Şiir, Mikosch'un eserinde şu misralarla aktarılmaktadır: (Mikosch, 1995, s. 242)

"Türklerin başı

Hessen ve Cassel bölgesinin saygıdeğer ve heybetli Prensi

Cesarette bir Müslüman'dan daha fazlası

Anu artık geri çekilmeye hiçbir düşman zorlayamaz

Böyle bir zarafette dahi

On ikiden fazla Saracen taşıyorsunuz

Türk kadınlarının bașı

Vitzthum eyaletinin düşesi

Oldukça etkili konuşuyorsunuz

Mükemmel derecede iyi yazıyorsunuz

Anlayışta ne zenginsiniz

Ve cesarette de öyle
Sağınızdaki ve solunuzdaki düşmana karşı (cesurca) dönersin

Aynı bir Türkün devletini savunduğu gibi.”

Bir eyalet prensinin bu denli Osmanlı kültürü ile hemhal olması Avusturya coğrafyasında pek de alışık olunmayan bir durumdur. Bunun altında yatan sebepleri bazı açılardan irdelemek gerekir. Birincisi, daha önce de bahsedildiği üzere Saksonya Eyaleti'nin Osmanlı saldırılarına doğrudan maruz kalmaması ve bu nedenle Osmanlı Devleti'ne karşı belirgin bir nefretinin olmamasıdır. İkincisi, VI. Karl'ın erkek bir evladı olmaması nedeniyle bu evliliğin Prens August'un imparator olması hususunda ona büyük bir şans vermesidir. (Schuckelt, 2010, s. 245) Zira August, düğününde kurulan tahtla Osmanlı Sultanı kadar güçlü olduğunu göstermek istemiş ve imparatorluğu daha da zengin hale getireceğine dair siyasal mesajlar vermeye çalışmıştır. Ancak VI. Karl tarafindan ilan edilen "Pragmatische Sanktion" adlı belgeyle August bu şansını kaybetmiş ve Avusturya tahtına imparatorun büyük kızı Maria Theresia oturmuştur. Üçüncüsü ise Osmanlı Devleti'nin başında bulunan sultanın yetkilerine ve haklarına özenilmesi ve böylesine özel bir günde sultan veya vezirler gibi davranılmak istenmesidir. (Mikosch, 1995, s. 235) Çünkü düğünde damat, Osmanlı'da sadece padişah ve vezirlere ait bir ayrıcalık olan tuğ taşımış ve ayrıca evlenecek çiftler için hazırlanan masa bir çadır içine konulmuş, böylelikle çadırın Osmanlı kültüründeki yerine atıf yapılarak gelin ile damadın makamının sultanlara veya vezirlere denk olduğu vurgulanmaya çalışılmıştır.

Bir diğer neden ise, söz konusu düğünün 1718 yılında imzalanan Pasarofça Antlaşması'ndan hemen sonra yapılması ve her iki devlet arasındaki ilişkilerin daha iyiye gittiğinin Türk usulü bir düğün yapılarak somut bir şekilde gösterilmesi olarak düşünülebilir. (Schuckelt, 2010, s. 246vd) Zira düğünün Viyana'da gerçekleşen bölümüne davet edilenler arasında Pasarofça Antlaşmasının karşılıklı teyidi amaciyla Viyana'ya 763 kişilik maiyeti ile gelen Osmanlı büyükelçisi Rumeli Beylerbeyi İbrahim Paşa da vardır. Viyana'nın Favoriten köyünde yapılan bu düğünde, İbrahim Paşa hem Kayser ve davetliler, hem de yeni evli çift tarafından büyük bir ilgiyle karşılanmıştır. İbrahim Paşa ise yeni evli çiftlere kırmızı Şam kumaşıyla sarılmış bir kutu içinde Türk şerbetleri hediye etmiştir. (Schuckelt, 2010, s. 245; Mikosch, 1995, s. 236) İmparatorun bu düğünde elçiye olan alakası ve düğünde Türk kültürüne yer verilmesine müsaade etmesinin nedeni ise Osmanlı Devleti ile yapılan bu barışa oldukça önem vermesi ve yeniden bir tehdidin ortaya çıkmasını istememesidir. Ayrıca imparator, oğlunun düğünü için oldukça cömert davranmış ve özellikle Osmanlı Devleti karşısında devletin mali durumunun yüksek ve güçlü olduğunu göstermek istemiştir. (Doubek, 2007, s. 102) Ancak genel olarak bakıldığında Saksonya ve Habsburg Hanedanlığının Osmanlı'ya karşı birbirinden farklı bir tutum sergilediği izlenimine ulaşılsa da, August der Starke'nin düğününde ön plana çıkardığı hususların genellikle askeri unsurlar olması düşündürücüdür. Zira yeniçeri kostümü giyen askerler, mehteran, tuğ ve sultan çadırı bu düğünde oldukça ön plandadır. Ayrıca düğünün Saksonya halkının açlık ve kıtlıkla mücadele ettiği bir dönemde yapılması ardında başka sebeplerin de olabileceğini düşündürmektedir.

Açık ve gizli politik mesajlarla dolu olan bu düğün, aslında Saksonya prensi için bir sınav durumundadır. August bir taraftan Roma Germen İmparatoru'na olan bağlılığını 
göstererek her iki hanedanlığın nesiller boyu Osmanlı'ya karşı mücadele ettiğini ve Osmanlı ile ilişkiler düzelse de savaşların asla unutulmayacağını bildirmek istemiş, diğer taraftan da yakın zamanda Kutsal Roma Germen İmparatorluğu tahtına oturacağını düşündüğünden Osmanlı ile dostane ilişkiler kuracağının da sinyallerini vermiştir. (Mikosch, 1995, s. 243)(Resim 5-6)

Avusturya'daki Türk modası, Osmanlı Devleti ve Avusturya'nın sınır komşusu olmasından dolayı Fransa ve Almanya'ya oranla daha yoğun yaşanmıştır. Zira her iki devlet uzun yıllar boyunca mücadele etmiş ve yaşanan askeri mücadelelerden sonraki gergin ortam ancak Pasarofça Antlaşmasından sonra sakinleșmeye bașlamıştır. Ayrıca Pasarofça Antlaşması'ndaki Avusturyalı tüccarlara Doğu'da ticaret yapma müsaadesinin tanıması da söz konusu etkileşime ivme kazandıran bir etkendir. Bahsedildiği üzere Saksonya ve Habsburg Hanedanlığı arasında gerçekleşen evlilik merasiminde bir Osmanlı elçisinin hazır bulunması, her iki devlet arasında gümrük serbestliği tanınması ve Avusturya'dan Osmanlı Devleti'ne mütercim-tercüman olması için gönderilen kişilerin Osmanlıcayı gayet iyi öğrenmesi ve devletlerarasında olumlu fikirler bildirmesi, iki devlet arasındaki ilişkilerin iyiye gitmesinde etkili olmuştur. (Galter, 6 April bis 4. November 2018, s. 97)

Her ne kadar Türk adetleri taklit edilmeye çalışılsa da bazı tiyatral ve spor etkinliklerinde Türklere karşı her an tetikte olunması gerektiği izlenimi üstü kapalı bir şekilde verilmiștir. Zira 1740 yılında Avusturya tacını giyen İmparatoriçe Maria Theresia, hem Osmanlı Devleti ile barış yapılmasına rağmen onlarla savaşabilecek kadar güçlü olduğunu diğer Avrupa devletlerine göstermek hem de Avusturya sarayında kendisine muhalif olan sesleri bastırmak için Türklerin rencide edildiği tiyatro ve spor etkinliklerine katılmıştır. (Schumann, 2003, s. 237) Ayrıca söz konusu yıllarda gazete kültürünün çok yaygın olmamasından dolayı bu tür etkinlikler, imparatoriçenin şahsi düşüncelerini açığa vurduğu, toplumun nabzını tuttuğu ve onlara yanında olduğunu göstermesi açısından da önemlidir. Nitekim 2 Ocak 1743 tarihinde Prag'ın yeniden fethi nedeniyle Maria Theresia tarafından Hofburg'daki Kış Binicilik Okulu'nda saat 10 'da başlayıp öğleden sonra 14.00'a kadar süren bir merasim düzenlenmiş ve burada bayanlar için "Frauen-Carrousels" adlı bir oyun oynanmıștır. (Wiener Zeitung, 5 Januar 1743, s. 7; Wienerisches Diarium, 9 Januar 1743, s. 11; Lau, 2016, s. 178) Bu oyuna Theresia'nın kız kardeşi Maria Anna, saray ve devlet adamları ile soylu beyefendilerin eşleri de gösterişli kıyafetleriyle katılmıştır. Oyuna göre; imparatoriçe kadın binicilerin öncülüğünü yapmakta, arabalar süvariler tarafından sürülmektedir. Kadınlar ise tahtadan veya kâğıttan yapılarak kazıklara geçirilmiş Türk kafalarını kılıç darbeleriyle vurarak bu oyunu devam ettirmekteydiler. (Resim 7-8)

XVII. yüzyıldan XIX. yüzyıla kadar Habsburg İmparatorluğu'nda devam eden bu oyun, hem sarayda hem de halk arasında oldukça yaygın bir eğlence türü olmuştur.

3 Ekim 1743 tarihinde, Avusturya'da Türk modası zirveye taşınmış ve imparatorluğun yönetim merkezi olan Schönbrunn Sarayı'nda “Orientalisches Fest” adıyla bir Türk festivali düzenlenmiştir. Bu festival hakkında Saray Kâhyası General Prens Johann Josef Khevenhüller-Metsch şunları söylemektedir: "Burada sadece büyük bir balo düzenlenmedi. Akşam balosunda yemek yenilecek alanın yanı sıra saray ve bahçenin orta kısmı da birçok fenerle aydınlatıldı ve yerel opera takımı Doğu kostümüyle bahçeye giriş yaptı ve bu kostümlerden birini giyen bir balet salonda dans etti". (Khevenhüller-Metsch, Graf, \& Schlitter, 1907, s. 179) Başta İmparatoriçe Maria Theresia olmak üzere devlet erkânı da Türk modasından etkilenmiş ve hatta Theresia ve kızı Maria Antoinette Türk modasından ne kadar etkilendiğini göstermek istercesine Türk kıyafetleri giyerek portrelerini yaptırmışlardır (Resim 9 ve 10). Türk kostümleri içinde Cenevreli ressam Jean-Etienne Liotard'a portrelerini çizdiren sadece Theresia değildir, bazı hanedan üyeleri de bu modaya kapılanlar arasındadır. (Knoch, 1960, s. 86)

Türklere ait simgeler veya onları çağrıştıracak eşyaların, sarayların balo salonlarını ve özel konutları süslemesinin dışında, kilise gibi ibadet mekânlarında da kullanıldığı görülmektedir. 1744 yılında Avusturya Kraliyet Kilisesi olarak da bilinen Loreto-Kapelle, Avusturya prensesi Maria Anna ve Prens Karl Alexander von Lothringen'in düğün merasimi için hazırlanmış, gelin ve damadın hemen arkasında oturacak alan bulamayan leydiler için bir yer düşünülmüş ve bu kısım da Türk halıları ile kaplanmıştır. Küçük bir detay gibi görülse de, bu halıların dönemin gazetesinde yer bulması geçiştirilmemesi gereken bir durumdur. (Wiener Zeitung, 1 Februar 1744, s. 16) Ancak aynı yılda (1744) yapıldığ 1 tahmin edilen Maria Theresia'nın madalyonlu portresinde Osmanl1-Avusturya arasındaki ilişkilerin hala çok gergin olduğu görülmektedir. Bahsi geçen kabartmalı madalyonda imparatoriçenin resmini Türkler taşımaktadır.(Resim 11) Resme dikkatlice bakıldığında madalyondaki portrenin Maria Theresia'ya ait olduğu ve onu taşıyan yeniçeri görünümlü "Türklerin" madalyonun altında diz çöktürülmüş bir vaziyette ezildiği anlaşılmaktadır. Söz konusu resmin yer aldığı Viyana Milli Kütüphanesi'nin internet sitesindeki "Bildnismedaillon Maria Theresias, getragen von Osmanen" cümlesi de, Maria Theresia'nın Osmanlılar (Yeniçeri) tarafindan taşındığı vurgulanmıştır. Resimden çıkartılabilecek birinci sonuç; imparatorluğunda ciddi dış problemlerle uğraşan imparatoriçenin Türklerin yardımına ihtiyaç duyması ve Osmanlı Devleti olmadan ayakta duramayacağı gibi; Osmanlı Devleti'nin zayıfladığı, Habsburg İmparatorluğu altında ezildiği ve artık eskisi gibi güçlü bir pozisyonda olmadığı, yani alt edildiği düşüncesi olabilir. Madalyonu imparatoriçenin kendisinin yaptırdığı düşünüldüğünde gücünü zayıf gösteren böyle bir durumu sembolize etmesi mantıksızdır. $\mathrm{Bu}$ sebeple ikinci yorum daha mantıklı durmaktadir.

1748 yılında ise Osmanl-Avusturya ilişkilerini hareketlendiren yeni bir gelişme yaşanmış ve Mustafa Hatti Efendi Avusturya'ya orta elçi unvanıyla gönderilmiştir. Osmanlı Devleti'ni temsil eden bu elçi başta İmparatoriçe Maria Theresia, İmparator I. Franz ve Viyana halkı tarafından merakla karşılanmıştır. Öyle ki, imparator ve imparatoriçe Osmanlı heyetinin şehre girişini ve Türklerin nasıl göründüğünü yakından takip edebilmek için kılık değiştirerek heyetin mola verdiği yerde gizlice onları takip etmiştir. (Savaş A. İ., 1991, s. 251)

Theresia ve eşinin iktidarda olduğu bu dönem, aynı zamanda Avusturya'da Veraset Savaşlarının yaşandığı ve komşuları tarafından sık sık tacize uğradığı bir dönemdir. Bu nedenle Prusya gibi bir düşmanla mücadele ederken, Osmanlı 
Devleti ile iyi geçinmek ve diğer Avrupalı devletler ile birlikte imparatorluğa bağlı ülkelerle de ilişkileri evlilik yolu ile güçlendirmek bir devlet politikası olarak görülmüştür. Nitekim bu dönemde Avusturya ile mücadeleye girmek istemeyen Osmanlı Devleti, imparatoriçenin ve Avusturya halkının büyük bir takdirini kazanmıştır. (Unat, 1968, s. 95)

Ayrıca Avusturya, Osmanlı Devleti'ne gönderdiği hediyeler ve elçilerle de bu durumun sadece sözden ibaret olmadığını göstermeye çalışmış ve imparatoriçe Mustafa Hatti Efendi ile görüşmesinde çocuklarını Türk dostu olarak yetiştirdiğini ısrarla vurgulamıştır. (Savaş A. İ., 1999, s. 1-2) Mustafa Hatti Efendi'nin Viyana sefareti ve onun beraberinde Avusturya sarayına getirdiği hediyeler Avusturya'daki Türk imajını farklı bir boyuta taşımıştır. Nitekim Osmanlı Devletine dost gözükmek amacıyla Hatti Efendi'nin sefareti esnasında bizzat onun tarafından kaleme alınmış ve Sultan I. Mahmud'un altın yaldız ile tuğrası çekilmiş bir dörtlük Avusturya sarayının salonuna asılmıştır. (Unat, 1968, s. 96) Ayrıca Hatti Efendi'nin gelişine, 22 Mayıs 1748 tarihinde yayımlanan Wiener Zeitung Gazetesi'nin çarşamba günündeki "Extra-Blatt" adlı ekinde oldukça geniş yer verilmiştir. Söz konusu haberde Osmanlı elçilerinin gelişinin her iki ülke arasındaki negatif durumu değiştireceğine ve Belgrad Antlaşmasının uzatılmasıyla gerçekleşen bu barış sürecinin önemine değinilmiştir. (Wiener Zeitung, 22 Mai 1748, s. 13) Bu sirada Avusturya sarayı tarafindan İstanbul'a da Herrn von Penkler gönderilmiştir. Hatti Efendi'nin seyahati, dönemin gazetesinde şu sözlerle aktarılmıştır:

"Bu yılın Ocak ayının sonunda yaklaşık 100 kişilik maiyeti ve 50'den fazla at ile Osmanlı elçisi, İstanbul'dan buraya doğru yola çıktı ve 12 Mart'ta Belgrad'a ulaştı. Burada birkaç gün kaldıktan sonra 18 Mart'ta Graenitz'den bu tarafa doğru ilerledi ve heyet gözükünce de ona İmparatorluk Sarayı'nın Doğu dillerine hâkim olan danışmanlarından Sekreter Schwachheim eşlik etti. En nihayet 8 Mayıs'ta elçi ve beraberindekiler Schwechat'a ulaştı. Daha sonra arabasından indi ve kahvesini ald 1 ve saat 8.00 'de atına bindi ve maiyetindekiler de onu Marxer-Linie (marxer hattı) boyunca takip etti. Şehre Viyana merkezdeki Landstrasse'de bulunan taş köprü üzerinden oradan da kırmızı kule kapısından geçerek girdi... (Bu kısımda Hatti Efendinin maiyetindekiler ve ona Avusturya tarafindan eşlik edenler tek tek sayılmıştır). 14. sırada Hatti Mustafa Efendi, astarlı samur yeşil kürk giyinmiş bir halde oldukça gösterişli bir atın üstünde 15-20 Çuhadar'ın yaya eşlik etmesiyle gözüktü, onların arkasında da omzunda tüfek taşıyan Bostancılar..." (Wiener Zeitung, 22 Mai 1748, s. 12-16)

Görüldüğü üzere, gazetede Hatti Efendi'nin Viyana'ya giriş merasimine, oldukça geniş yer verilmiştir. Avusturya yönetimi Hatti Efendi'nin karşılanmasında Türk kültürüne uygun olarak bir karşılama tertiplemiştir. $\mathrm{Bu}$ bağlamda Mustafa Hatti Efendi'nin karşılanması sırasında 6 koşumlu bir araba hazırlanmış ve atlar da Türk usulüne uygun olarak süslenmiş, sürücüye de Türk kıyafetleri giydirilmiştir. (Wiener Zeitung, 1 Juni 1748, s. 13; Wiener Zeitung, 19 Juni 1748, s. 11) Elçiyi karşılamakla yükümlü olan saray danışmanlarından Graf von Harrach, doğu dillerini akıcı bir şekilde konuşan sekreter Momarz'1 da her daim yanında hazır bulundurmak suretiyle, yanlış anlaşılmaların önüne geçmeyi amaçlamıştır. (Wiener Zeitung, 1 Juni 1748, s. 1316)
Ancak Hatti Efendi'nin imparatoriçe Maria Theresia ile görüşmesinde karşılıklı ılımlı gözükme çabası az da olsa zarar görmüş ve Hatti Efendi'nin imparatoriçeyi Avusturya saray adabına uygun olarak selamlaması istenmiştir. Ancak Hatti Efendi ve maiyetindekiler, Vizekanzler Graf von Colleredo'nun söz konusu selamlama hususunda israrına rağmen imparatoriçeyi Türk usullerine göre selamlamış - diz çökmeden, tahtın önündeki basamağın yanında durarak İmparatoriçenin mantosunu öpmüştür- ve yine Türk usulüne uygun olarak da üçlü reverans selamlaması yaparak arka arkaya yürüyerek huzurdan ayrılmıştır. (Wiener Zeitung, 19 Juni 1748, s. 14)

Hatti Efendi'nin sefareti esnasında 13 Nisan 1748 tarihinde Avusturya gazetelerinde enteresan bir reklama rastlanılmış ve reklamda -Türk elçisinin etkisinden mi yoksa Türk eşyalarına talebin gitgide artmasından mıdır bilinmezTürklere ait çeşitli silahların, bıçakların ve kavisli Türk k1lıcinın 18 Nisan 1748 tarihinde Berghof'da bulunan "Schwertfegerischenhaus" da 9-12 saatleri arasında satışa çıkarılacağı bildirilmiştir. (Wiener Zeitung, 13 April 1748, s. 12) $\mathrm{Bu}$ tür silah reklamlarına ilk kez bu dönemde rastlanılmamaktadır. Nitekim Türklerle ilişkilerin oldukça gergin olduğu dönemlerde silah veya da askeri malzeme reklamları gazetelerde yer almaktadır. Örneğin, 1728 tarihli Wiener Zeitung gazetesinde yer alan bir haberde; II. Viyana kuşatması esnasında ele geçirilen Türklere ait birçok eşyanın da sergileneceği ve bunların satışa çıkarılacağı reklamı bir sergi reklamı yapılmıştır. (Wiener Zeitung, 11 Februar 1728, s. 8) 1754 tarihli başka bir haberde ise terk edilmiş eşya satışı reklamı verilmiş ve bu eşyaların çoğunluğunun Türklere ait eşyalardan oluştuğu görülmüştür. (Wiener Zeitung, 12 Juni 1754, s. 7) Benzer bir açık artırma silahlar üzerinde değil de dekorasyon malzemeleri üzerinde yapılmıştır. 11 Mart 1761 günü yayınlanan gazetedeki ilanda Türk motifli cam ürünlerin en yüksek teklifi verene satılacağının ilanı verilmiştir. (Wiener Zeitung, 11 Marz 1761, s. 11)

Mustafa Hatti Efendi'nin 169 günlük seyahati Avusturyalıların Türkleri yakından tanıması için bir firsat sağlamıştır. Zira Hatti Efendi'nin her hareketi ilgiyle izlenmiş ve onun Schwechat kasabasında mola verdiğinde kahvesini içmesi dahi bilahare belirtilerek haberleştirilmiştir. II. Viyana Kuşatması sonrasında Türklerden Avusturyalılara ganimet olarak kalan kahve, tütün tabakaları, Türk kılıçları ve Kara Mustafa Paşa'ya ait çadır bu tarihten sonra Avusturya'da Türkleri ifade eden semboller olarak kullanılmıştır.

Gerçi 1645 yılından itibaren Türk elçileri için saray masrafları arasında Türk kahvesi harcaması gözükse de halkın kahve kültürü ile tanışması II. Viyana Kuşatmasından sonra olmuş ve 1685 yılında Viyana'da ilk kez Luigi Conte Marsigli tarafından Türk kahvesinin de özellikle yapıldı ğ bir kahvehane açılmıştır. (Czeike, 2004, s. 409-410) Lüks bir tüketim olan ve halkın geneli tarafindan pahalı olmasından dolayı alınmayan kahve, 1748 yılında Avusturya topraklarına ayak basan bir Osmanlı elçisi ile toplum nezdinde yeniden karşıllı bulmuştur.

1754 yılında Viyana'da açılan ve "Orientalische Institut" olarak bilinen Şark Bilimleri Akademisi, iki devletin ilişkilerinde yakınlaşma sağlanması amacıyla açılan ilk müessesedir. Aslında bu okulun açılması siyasi ve askeri bir politikanın gereğidir, zira Avusturya'nın komşusu olan Osmanlı Devleti ile savaşmadan diplomatik ilişkiler 
yürütebilmesi ancak Osmanlıca, Arapça ve Farsça bilen diplomatların yetiştirilmesi ile mümkündür. (İstek, 2017, s. 162) Söz konusu akademiden başarıyla mezun olanlar, her iki devlet arasındaki antlaşmaların uzatılması ve ilişkilerin sulh içinde devam etmesi amacıyla İstanbul'da veya Viyana Sarayı'nda görevlendirilmiştir. Nitekim 1792 yılında Viyana'ya elçi olarak gönderilen Ebubekir Ratip Efendi'ye Viyana'daki gezilerinde yardımcı olan bu akademi mezunu Joseph Purgstall von Hammer'dir. Ayrica bu akademide Kraliyet ailesi üyeleri Türkçe tiyatrolar da izlemekteydiler. (Wiener Zeitung , 11 Marz 1761, s. 6)

Şark Bilimleri Akademisi'nin kurulmasından tam 3 yıl sonra, Osmanlı Devleti'nde bir taht değişikliği yaşanmış ve tahta geçen Sultan III. Mustafa'nın cülusunu bildirmek üzere Ahmet Resmi Efendi (Resim 12) Viyana’ya gönderilmiştir. (Kütükoğlu, 1989, s. 121) Avusturya'nın Prusya ve Fransa tehdidi altında olmasından dolayı Osmanlı Devleti ile ilişkilerinin bozulmamasına dikkat ettiği Resmi Efendi’nin sefareti sırasında bir kez daha görülmektedir. Bu dönemde Avusturya'da Türk elçilerine gösterilen hürmetin yanı sıra Türk ürünlerine rağbet de vardır. Nitekim 1765 yılında Maria Theresia'nın ikinci büyük oğlu Arşidük Leopold'un İspanya prensesi Maria Ludovica ile Innsbruck eyaletindeki bir kilisede evlilik merasimi gerçekleşmiş ve merasimde tören yapılan zeminin büyük bir kısmı Türk halıları ile kaplanmıştır. (Hanzl-Wachter, 2004, s. 50-52)

1740-1773 arasındaki yıllar Avusturya'da Türk lalelerinin de oldukça revaçta olduğu bir dönem olmuştur. 28 Eylül 1740 tarihinde yayımlanan gazetede Montani kardeşler tarafindan ülkeye getirilen çiçekler ve çiçek soğanları reklamı yapılmış ve bunlar arasında her çeşit ve renkten Türk laleleri de yerini almıştır. (Wiener Zeitung, 28 September 1740, s. 12) Montani kardeşlerin Türk laleleri satışının 1773 yılına kadar da devam ettiği anlaşılmaktadır. (Wiener Zeitung , 27 November 1773, s. 20) Bu durum da Avusturya'da hala Türk etkisinin ve Türk lalelerine talebin sürdüğünü göstermektedir. Ancak 1768 yılından itibaren artık Türk laleleriyle beraber Hollanda'dan getirilen lalelerin de ithalatının yapıldığı göze çarpar. Lalelerin yanı sıra gazetelerde reklamı yapılan diğer bir Türk ürünü de "İnce Türk kâğıdı" veya "Çiçekli Türk kâğıdı" olarak özellikle belirtilen Türk usulüne uygun olarak hazırlanmış kâğıtlardır. (Wiener Zeitung, 28 Juli 1734, s. 4)

“Alla Turca" modası sadece günlük yaşam ve mimari de kullanılmamış, sanat ve musikiye de sıçrayarak 1770 yılına kadar birçok Avrupa ülkesinin askeri bandolarını da etkilemiş ve mehterhane tarzında müzikler bestelenmeye başlanmıştır. (Groote, 2011, s. 70) Ordu mensuplarının haricinde ünlü bestekârlar da bestelerinde bu akımdan etkilenmiştir.

Bestelerinde Türkleri konu alan bestekârların başında Avusturyalı ünlü bestekâr Wolfgang Amadeus Mozart gelmektedir. Mozart "Zaide", "Saraydan Kız Kaçırma” ve "Alla-Turca-Marşı”" gibi çalışmalarında Türk esintilerinden faydalanmıştır. 16 Temmuz 1782 yılında gösterime giren "Saraydan Kı Kaçırma" adlı komedi müzikali, Avusturya'daki Türk akımını günümüze taşıyan bir proje olmuştur. (Wiener Zeitung, 7 August 1782, s. 10) Müzikalde konsepte uygun olarak davul, üçgen, zurna ve zil gibi Türk/Doğu enstrümanları da kullanılmıştır. Ancak söz konusu gösterinin II. Viyana Kuşatmasının 100. yıldönümüne bir yıl kala yapılması tesadüfî olmasa gerektir.
Müzikal, Türklerin elinde esir olan genç bir kadın ve hizmetçi üzerinde kurgulanmış ve özellikle Osmanlı'daki cariye sistemi kastedilerek "kadınların alınıp satılabilecek bir meta olmadığg” düşüncesi verilmeye çalışılmıştır. Bu dönemde Osmanlı ve Avusturya arasındaki ilișkilerin Rusya'nın dâhil olmasıyla gerginleşmesi, müzikal içine bazı politik mesajların sığdırılmasına ve Türklere karşı beslenen negatif duyguların Selim Paşa karakteri üzerinden ortaya konulmasına neden olmuştur. Zira Kayzer II. Joseph oyun sonrasında Mozart'a 'Sevgili Mozart! Kulaklarımız şenlendi ve birçok önemli notlar aldılar" diyerek oyunun vermek istediği asıl mesajın yerine ulaştığını belirtmiş ve Mozart da imparatora "Majesteleri, dediğiniz gibi verilmesi gereken birçok mesaj vardı" cevabıyla karşılık vermiştir. (Friehs, 20.01.2019)

Mozart masonlardan aldığı maddi ve manevi destekle oyunlarını birçok Alman şehirlerinde oynatmayı başarmış ve onların fikriyatına da hizmet etmiştir. "Zaide" ve "Saraydan Kız Kaçırma" oyunu her ne kadar hümanist ya da insan sevgisiyle yazıldığı öngörülse de (Kanca \& Yücel, 2003, s. 242), aslında Osmanlı'ya karşı gizli mesajlar içeren ve imparatorluğun şemsiyesi altına saklanarak politik meselelerden yararlanan bir etkinlik olmuştur. Nitekim Mozart, Maria Theresia döneminde devlet ricalinin arzusu üzerine Türk temasını müziğine yansıtmış ve bu nedenle de kendisine ihsanlarda bulunulmuştur. (Kanca \& Yücel, 2003, s. 244) Ancak II. Joseph döneminde Mozart'in müziği beğenilmesine ve oyunlarında imparatorun politik düşüncesine hizmet eden mesajlar vermesine rağmen, bu oyunlar onu sarayda istediği makama getirememiştir.

1780 yılında Maria Theresia'nın vefatı sebebiyle tek başına Avusturya tahtına çıkan Kayser II. Joseph, ülkesindeki iç karışıklıkları bastırabilmek için Rusya'dan yardım istemiş ve Rusya'nın da kışkırtmasıyla Osmanlı Devleti ile neredeyse 40 yıl ara verilen mücadeleler yeniden başlamıştır. Ancak 1790 yılında tahta çıkan İmparator II. Leopold kardeşinden farklı düşünerek, iki devlet arasındaki askeri mücadeleleri 1792 yılında imzalanan Ziştovi Antlaşması ile sonlandırmıştır. Osmanlı Devleti antlaşmanın karşılıklı onayı ve antlaşma nüshalarının verilmesi amacıyla Ebûbekir Râtib Efendi’yi Viyana'ya göndermiş, Râtib Efendi’nin görevlerinden birisi de Avusturya'nın idari askeri ve ekonomik sahalardaki yeniliklerini öğrenmektir. (Uçman, 2012, s. VI-VII)

Ratip Efendi'nin sefareti bu yüzyılın sonlarında AvusturyaOsmanlı ilişkilerini aktarmada ve Avusturya'daki Osmanlı imajını ortaya koymakta oldukça önemlidir.

Zira Râtib Efendi'nin oldukça entelektüel olması, cömertliği, yeniliklerden haberdar oluşu ve iyi bir devlet adamı portresi çizmesi Avusturyalıları hayran bırakmış ve girilmesi zor olan askeri kurumlara dahi girişini kolaylaştırmıştır. (Yeşil, 2010, s. 95) Râtib Efendi'nin farklı güzergâhlarda karşılanması ve ona tahsis edilen konak, at ve hizmetlilerin Türk adetlerine ve usulüne uygun olarak süslenmesi bu dönemde Avusturya'daki Türk imajı ve Türklere bakışın nasıl olduğu hakkında bir fikir verebilir. (15 Februar 1792, s. 398-399; Wiener Zeitung, 22 Februar 1792, s. 463-464)

Avusturya'daki Türk akımını 19. yüzyılda da görmek mümkündür. 1880 Avusturya Prensi Rudolf'un çalışma odasını Türk usulüne uygun olarak döşemesi (Resim 13) kanaatimizce o zamana kadar geçen Alla-Turca modasında 
görülmeyen bir husustur. (Mattes, 2002, s. 53) Eva B. Ottilinger, 1886 tarihli Allgemeine Illustrierte Zeitung gazetesinden aldığı haberde bu odanın şu şekilde aktarıldığını görmüştür: "Genel olarak doğu halıları iç mekânın en önemli ve en güzel kısımları. Odanın sol köşesinde İran halılarının üzerinde yer alan sofalar ve divanlar mevcut. Çadır benzeri çatı devasa bir kartalın pençeleriyle tutturulmakta. Divanda, eşek cepleri olarak adlandırılan iki büyük yastık sırtlık kısmını oluşturmaktadır. Divanın önünde ise masif gümüşten yapılmış ve büyük bir ustalıkla oyulmuş Arap usulü bir orta sehpa var ve masanın etrafında ise gümüş, sedef ve fildişi kakmalarla yapılmış birçok Türk usulü tabureler var" (Ottilinger, 1997, s. 96). Prensin bu kadar doğu hayranı olmasında 1878 yılında Bosna- Hersek'in Avusturya tarafindan işgali ve Avusturyalıların bunun sonucunda Osmanlı medeniyetini daha yakından görmesi etkilidir. (Haberlandt, 1894, s. 25) Ayrıca prensin 1881 yılında Kahire, Yukarı Mısır, Süveyş Kanalı ve Filistin'e yaptığı "Doğu Gezisi" nin böyle bir odanın oluşturulmasında büyük bir etkisi olmuş ve prens, bu seyahatinde Doğu'nun yaşam kültürünü yakından tanıma firsatı bulmuştur. (Ottilinger, 1997, s. 94)

\section{Sonuç}

Toplumlar tarafindan üretilen kültürel olguların dönem dönem dalgalar halinde diğer toplumları etkilemesi, devletlerin güçleri ve aralarındaki münasebetle doğru orantılıdır. Günümüze kadar süregelen genel yargıya göre; Osmanlı toplumu son yüzyıllarını Batı'dan etkilenerek geçirmiştir. Ancak bu çalışma sonucunda, söz konusu etkilenmenin, 18. yüzyılda karşılıklı olduğu ortaya konmuştur. Özellikle Batı'ya yönelimin miladı olarak görülen "Lale Devri", aynı zamanda -ışı̆̆ın ayna tarafından yansıtılması gibi- Osmanlı kültürünü, Osmanlı Devleti'nin yüzyıllarca komşusu olmuş Avusturya topraklarına taşınmasında etkili kıldı ve Türk laleleri bu dönemden sonra Avusturya pazarında yer buldu. Alla-Turca olarak isimlendirilen Türk modası sadece Lale Devri'nin bir sonucu olmaktan ziyade Osmanl1-Avusturya arasında yapılan savaşların da bir neticesidir. II. Viyana Kuşatmasıyla Viyana'da yaygınlaşan Türk kahvesi ve ayçöreği bunun önemli bir göstergesidir. Ayrıca Pasarofça Antlaşması ile başlayan Avusturyalı tüccarların Osmanlı ülkesinde ticaret yapma serbestliği, Doğu'nun mallarını ve haliyle kültürünü ülkelerine taşımalarını mümkün kılmıştır. İleriki dönemlerde Orient/Türk kıyafetlerinin saray içlerine kadar ulaşması bu tüccarların çabasının bir sonucu olsa gerektir. Bütün bunların yanı sıra ezeli düşman olarak görülen Osmanlı Devleti, bilhassa İmparatoriçe Maria Theresia'nın tahtının koruma politikasının da bir sonucu olarak Türk modasının etkisinin en çok görüldüğü dönem olmuştur. Bu dönemde düğünler, kilisedeki törenlerde göze çarpan doğuya has sergiler, Avusturya'ya seyahat eden Osmanlı elçilerinin ilgiyle karşılanmaları ve dönemin gazetelerinin elçilerinin kıyafetlerinden yeme içmelerine kadar her hareketlerini takip etmeleri, Türk kültürü ve modasına olan yakın alakayı ortaya koymaktadır. Aynı şekilde Avusturyalıların savaş meydanlarında duydukları Mehteran müziği sadece Avusturya'da değil Avrupa'nın birçok bölgesinde seslendirilmeye başlanmıştır. Yine opera ve tiyatro oyunları da -bir hiciv tarafının olduğunu yok saymayarak- Avusturya saraylarının vazgeçilmezleri arasında girmiştir.
Son söz olarak, 18. yüzyıl Avusturya'sında Alla-Turca etkisinin görülmesi Alman toplumunun bu modayı içselleştirmesi veya Türklerle yakınlaşmanın bir resmi gibi okunmamalı, ancak bir moda ve Doğu mistisizminin yansıması olarak idrak edilmelidir.

\section{Kaynakça}

(13.09.2019).

http://www.eslam.de/begriffe/s/schwetzinger_schlossgarten .htm adresinden alındi.

(08.01.2019).

http://www.zacherlfabrik.at/all/geschichte.html adresinden alind 1

(09.01.2019).

https://onb.ac.at/forschung/forschungsblog/artikel/ne ws/mozart-ein-freimaurer/ adresinden alındı

(10.01.2019).

http://www.zacherlfabrik.at/all/geschichte.html adresinden alınd 1

Friehs, J. T. (2019, 01 10). Türken in Wien! Die "Entführung aus dem Serail" am Wiener Burgtheater. www.habsburger.net:

https://www.habsburger.net/de/kapitel/tuerken-wiendie-entfuehrung-aus-dem-serail-am-wienerburgtheater adresinden alınd1.

Arslan, M. (2008). Osmanlı Saray Düğünleri ve Şenlikleri. Manzûm Sûrnâmeler (Cilt I). İstanbul: Sarayburnu Kitaplığı.

Auffgebot ... so die Chur- und Fürsten zu Sachsen ... an alle Landstende ... des Türcken ... halben ... verkündigen lassen . (1541).

Cantemir, D. (1745). Geschichte des osmanischen Reichs nach seinem Anwachse und Abnehmen. Hamburg.

Czeike, F. (2004). Historisches Lexikon Wien (Cilt III). Wien.

Doubek, K. (2007). August Der Stark. Hamburg .

Galter, H. (6 April bis 4. November 2018). Passarowitz Und Die Anfaenge Der Orientalistik İn Österreich. Wir Und Passarowitz. 300 Jahre Auswirkungen Auf Europa, Universalmuseum Joanneum, 94-102.

Groote, I. M. (2011). Musik in der Geschichte - Zwischen Funktion und Autonomie. München: Herbert Utz Verlag.

Haberlandt, M. (1894). Aus Bosnien Und Herzegowina. Österreichische Monatsschrift Für Den Orient.

Hammer, J. V. (1836). Geschichte Des Osmanischen Reiches (Cilt IV). Pest: C.U.Hartlebens's Verlag.

Hanzl-Wachter, L. (2004). Hofburg Zu Innsbruck. Wien/Köln/Weimar: Böhlau Verlag.

İstek, G. (2017). İlk Yenileşme Döneminde Avusturya'da Eğitim Ve Osmanlı Sistemi İle Mukayesesi (17741824). (Basılmamış Doktora Tezi). Diyarbakır: Dicle Üniversitesi Sosyal Bilimler Enstitüsü. 
Kanca, Ş. F., \& Yücel, F. (2003). Mozart Ve Sark. $\operatorname{KKEFD(8),~239-245.~}$

Khevenhüller-Metsch, Graf, R., \& Schlitter, H. (1907). Aus Der Zeit Maria Theresias. Tagebuch Des Fürsten Johann Josef Khevenhüller- Metsch (1742-1744). Wien/Leipzig.

Knoch, W. J. (1960). Short History Of Austria And The Habsburgs. Knoch.

Koçak Z. (2018). Son Osmanl1-Avusturya Mücadelesinde Değişen Dengeler ve Ziştovi Antlaşması. Akademik Bakış Dergisi. II(22). 261-289..

Kruschkova, K., \& Lipp, N. (2004). Tanz Anderswo: İntraUnd İnterkulturell, Jahrbuch Tanzforschung (Cilt XIV). Münster.

Kütükoğlu, B. (1989). Ahmed Resmî. TDV İslam Ansiklopedisi, II, 121-122.

Lau, T. (2016). Die Kaiserin Maria Theresia. Wien/Köln/Weimar : Böhlau Verlag.

Mattes, S. (2002). Orient im Film. Die Geschichte des Bauchtanzes von Seinen Anfaengen Bis Zur Gegenwart. Wien.

Mayr, J. (1607). Wachtshausel wider die Tüchter. München.

Mikosch, E. (1995). Ein Serial Für Die Hochzeit Des Prinzen. Turquerien Bei Den Hochzeitsfeierlichkeiten in Dresden im Jahre 1719. Im Lichte Des Halbmonds. Das Abendland Und Der Türkische Orient, 235-243.

Ottilinger, E. B. (1997). Kronprinz Rudolfs- Türkisches Zimmer" Und "Die Orientmode İn Wien". Orient : Österreichische Malerei Zwischen 1848 Und 1914. (E. M. Oehring, Dü.) Residenzgalerie Salzburg (20 Temmuz - 24 Eylül ).

Rexheuser, R. (2015). Die Personalunionen Von SachsenPolen 1697-1763 Und Hannover-England 1714. Ein Vergleich (Cilt XVIII). Wiesbaden: Harrassowitz Verlag.

Richter, S. (2008). Die Schweitzinger Moschee- Ein Tempel Der Weltweisheit? H. Neuhaus içinde, Archiv Für Kulturgeschichte (s. 109-129). Köln/ Weimar/ Wien: Böhlau Verlag.

Savaş, A. İ. (1991). Mustafa Hatti Efendi'nin Viyana Sefaret Raporu Üzerine. On Dokuz Mayis Üniversitesi Eğitim Fakültesi Dergisi, VI(1), 241-260.
Savaş, A. İ. (1999). Mustafa Hatti Efendi. Viyana Sefâretnâmesi. Ankara : TTK Yayınları.

Schuckelt, H. (2010). Die Türckische Cammer. Sammlung Orientalischer Kunst in Der Kurfürstlich-Sächsischen Rüstkammer Dresden. Dresden .

Schumann, J. (2003). Die Andere Sonne. Kaiserbild Und Medienstrategien im Zeitalter Leopolds I. Berlin.

Uçman, A. (2012). Ebûbekir Râtib Efendi'nin Nemçe Sefâretnâmesi. İstanbul: Kitabevi.

Unat, F. R. (1968). Osmanlı Sefirleri Ve Sefaretnâmeleri. (B. S. Baykal, Dü.) Ankara: TTK Yayınevi.

Wiener Zeitung . (1 Februar 1744).

Wiener Zeitung . (11 Marz 1761).

Wiener Zeitung . (15 Februar 1792).

Wiener Zeitung . (22 April 1758).

Wiener Zeitung . (27 November 1773).

Wiener Zeitung. (1 Juni 1748).

Wiener Zeitung. (11 Februar 1728).

Wiener Zeitung. (12 Juni 1754).

Wiener Zeitung. (13 April 1748).

Wiener Zeitung. (19 April 1758).

Wiener Zeitung. (19 Juni 1748).

Wiener Zeitung. (22 Februar 1792).

Wiener Zeitung. (22 Mai 1748).

Wiener Zeitung. (28 Juli 1734).

Wiener Zeitung. (28 Juli 1734).

Wiener Zeitung. (28 September 1740).

Wiener Zeitung. (5 Januar 1743).

Wiener Zeitung. (7 August 1782).

Wienerisches Diarium. (9 Januar 1743).

Wienerisches Diarum . (25 Ekim 1719).

Yeşil, F. (2010). Aydınlanma Çağında Bir Osmanlı KâtibiEbubekir Râtib Efendi. İstanbul : Tarih Vakfi Yurt Yayınlar1. 


\section{Ekler}

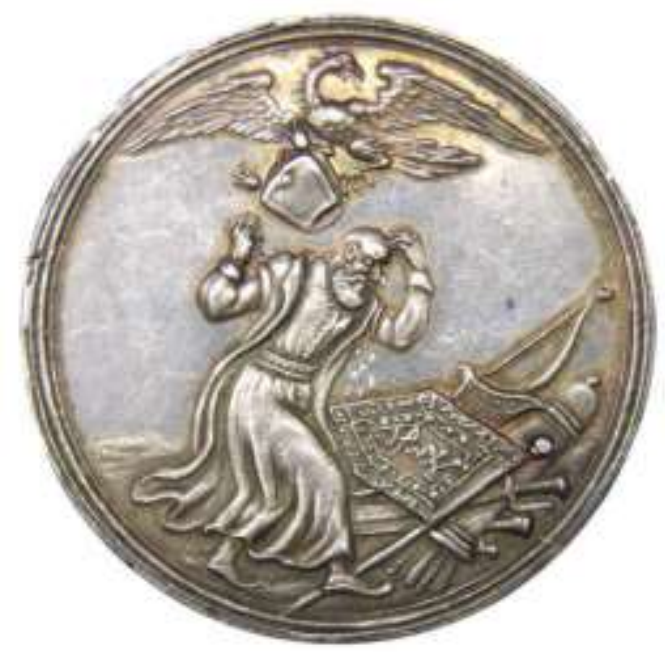

Resim 1: Vezir Kara Mustafa Paşa'nın II.Viyana Kuşatması'nda yenilmesi üzerine hazırlanmış bir sikke. (Hans Jakob Wolrab, Staatliche Museen zu Berlin im Münzkabinett. Im Lichte des Halbmonds, Katalog zur Ausstellung (1995) 204 Nr. 225)

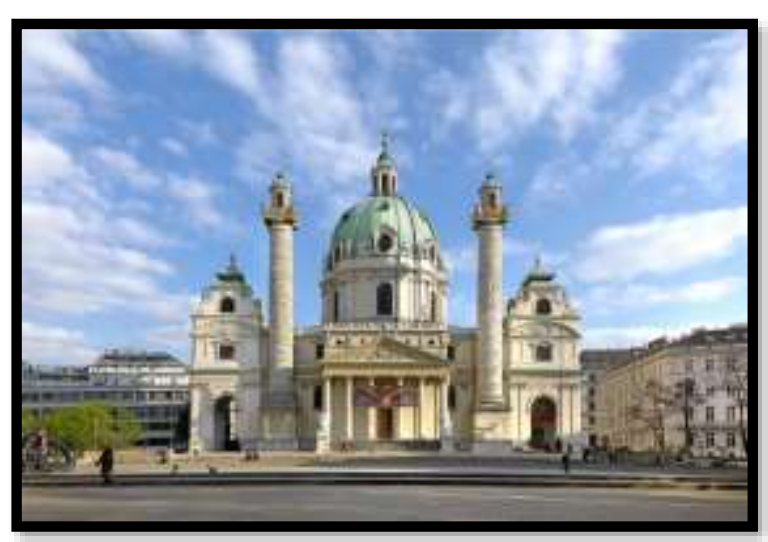

Resim 2: Viyana'da bulunan

Karlskirche (http://www.karlskirche.at/ E. T. 13.09.2019)

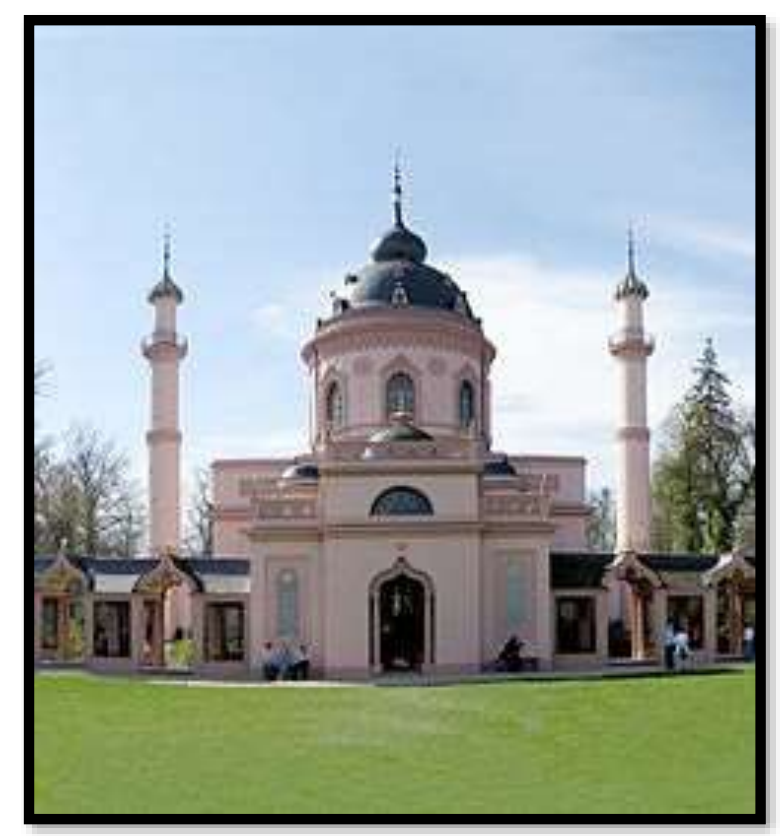

Resim 33: Die Schwetzinger Moschee

(http://www.eslam.de/begriffe/s/schwetzinger_schlossgarte $\underline{\text { n.htm }}$ (E.T. 13.09.2019))

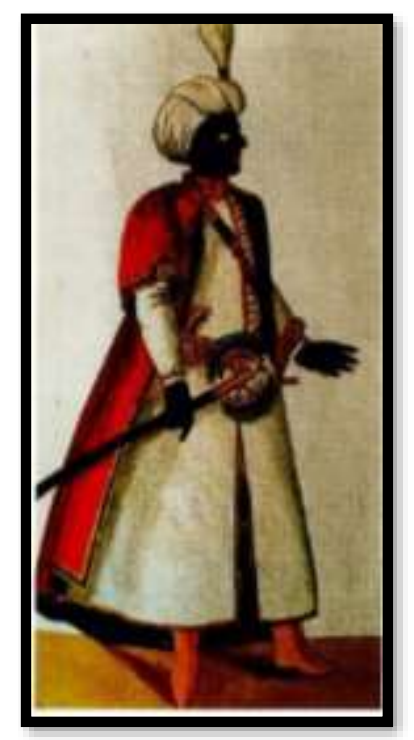

Resim 4: Anna Maria Werner tarafindan resmedilmiş 1719 yılındaki düğünün girişinde bekleyen Osmanlı kıyafeti giymiş bir kişi. (Kupferstichkabinett DresdenInventarnummer: C 6751. Bu resim; Claudia Schnitzler, "Zwischen Kampf und Spiel. Orientrezeption im höfischen Fest”, Im Lichte des Halbmonds. Das Abendland und der türkische Orient, hrsg. Staatliche Kunstsammlung Dresden/Kunst- und Ausstellungshalle der Bundesrepublik Deutschland Bonn, Dresden 1995, s. 237'den alınmıştır. 


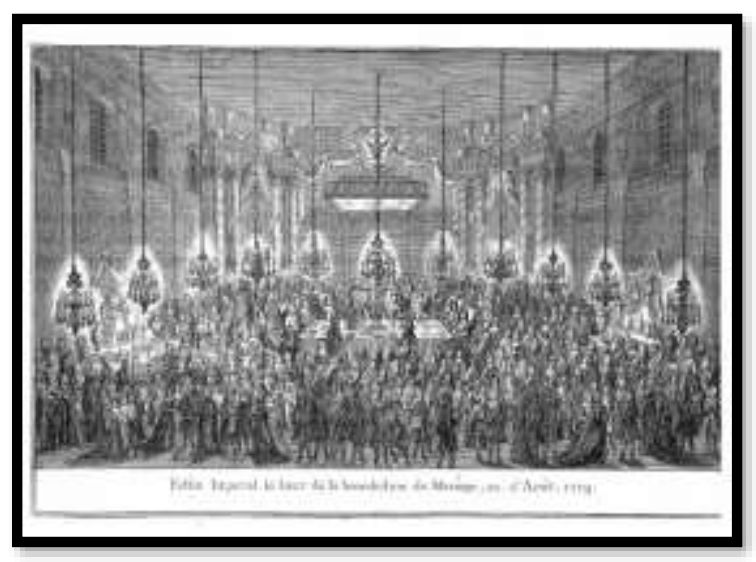

Resim 55: Louis Gérard Scotin tarafindan resmedilmiş 20 Ağustos 1719 tarihinde gerçekleştirilen düğün. (Andreas Gugler, Peter Parenzan (Hrsg.), Tafeln bei Hofe. Zur Geschichte der fürstlichen Tafelkultur, Hamburg/Dölling/Galitz 1997, s.5)

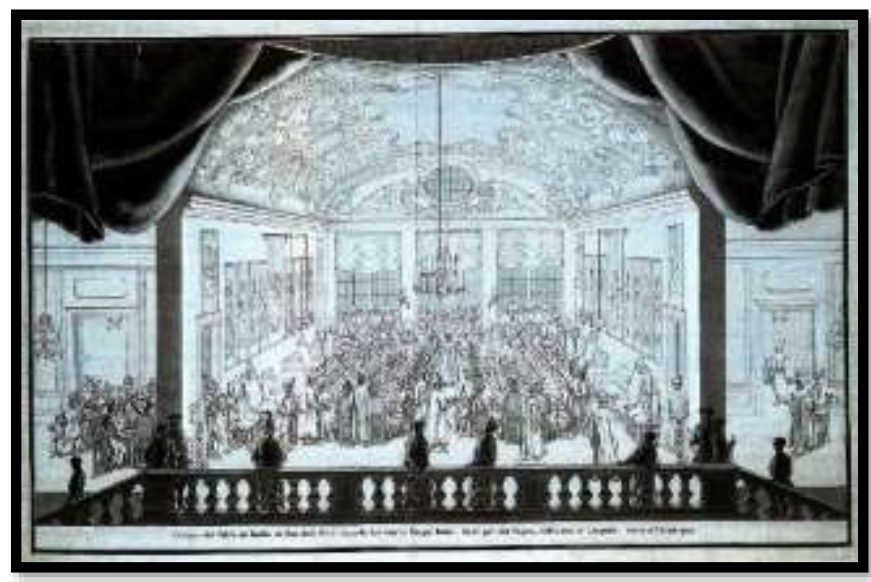

Resim 66: Carl Heinrich Jacob Fehling tarafindan 1729 yılında resmedilmiş Türk Sarayına Davet-1719 temalı balo. (Kupferstichkabinett Dresden, Inv.-Nr. C 6681. Resim; Claudia Schnitzler, "Zwischen Kampf und Spiel. Orientrezeption im höfischen Fest", Im Lichte des Halbmonds. Das Abendland und der türkische Orient, hrsg. Staatliche Kunstsammlung Dresden/Kunst- und Ausstellungshalle der Bundesrepublik Deutschland Bonn, Dresden 1995, s. 239'dan alınmıştır)

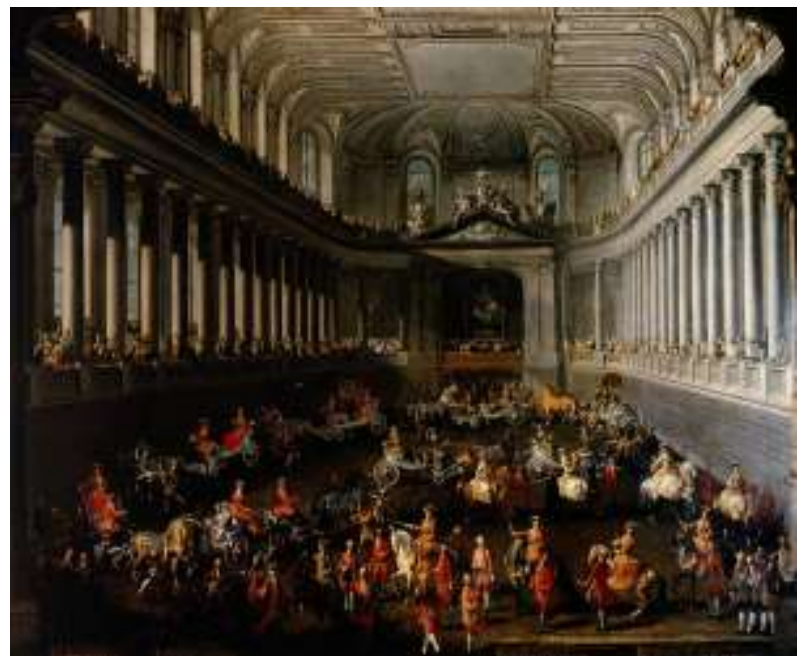

Resim 77:Martin van Meytens und Werkstatt: "Carussel in der Winterreitschule d. Hofburg v. 2. Jänner 1743", Ölgemälde, nach 1763

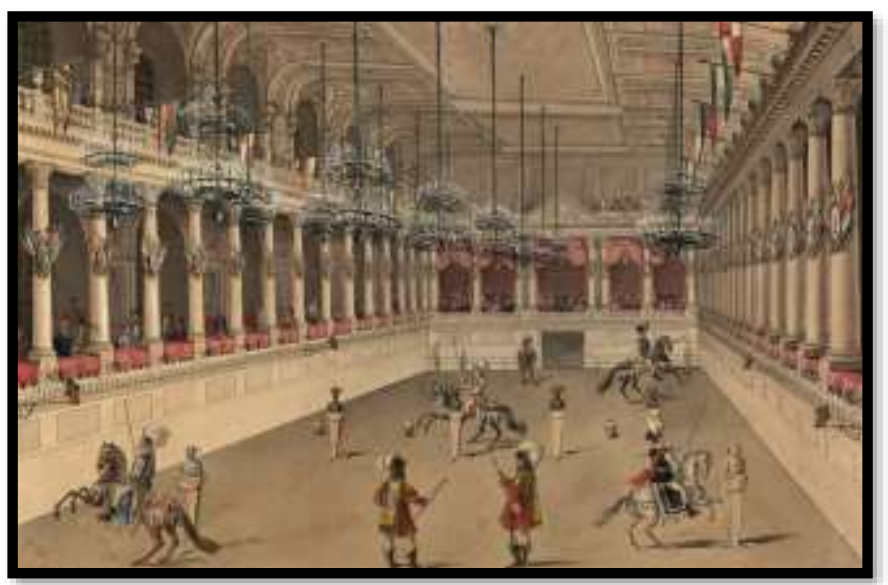

Resim 88: "Türkenkopfstechen" am Hof (http://www.habsburger.net/de/kapitel/tuerkenkopfstechenam-hof)

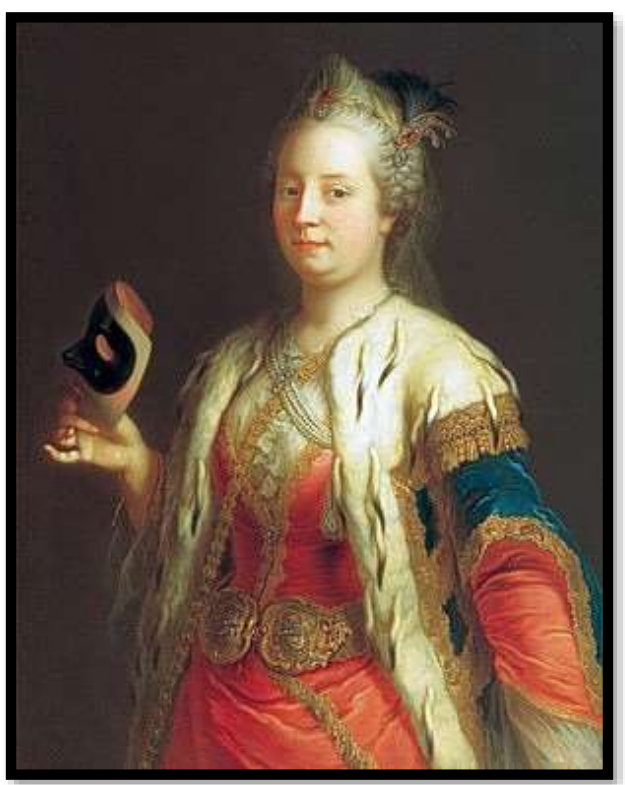

Resim 99:Martin van Meytens: Maria Theresia mit Maske in einem türkischen Gewand, um 1744 


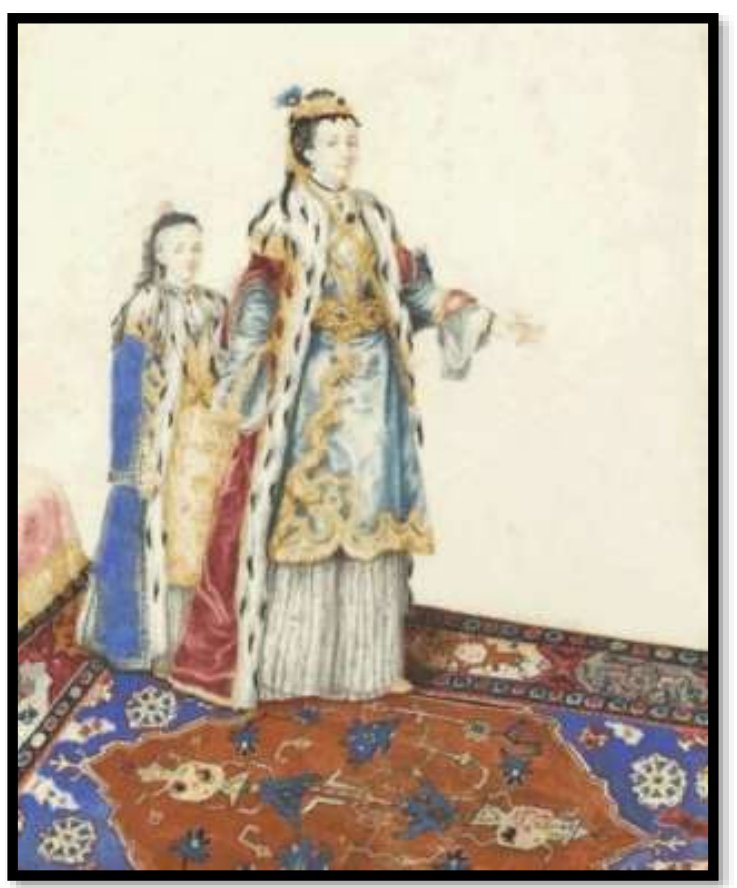

Resim 1010: Maria Theresia und ihre Tochter mit den türkischen Kleid- http://harmonie-der-herzen.at/habsburgerund-osmanen-2/

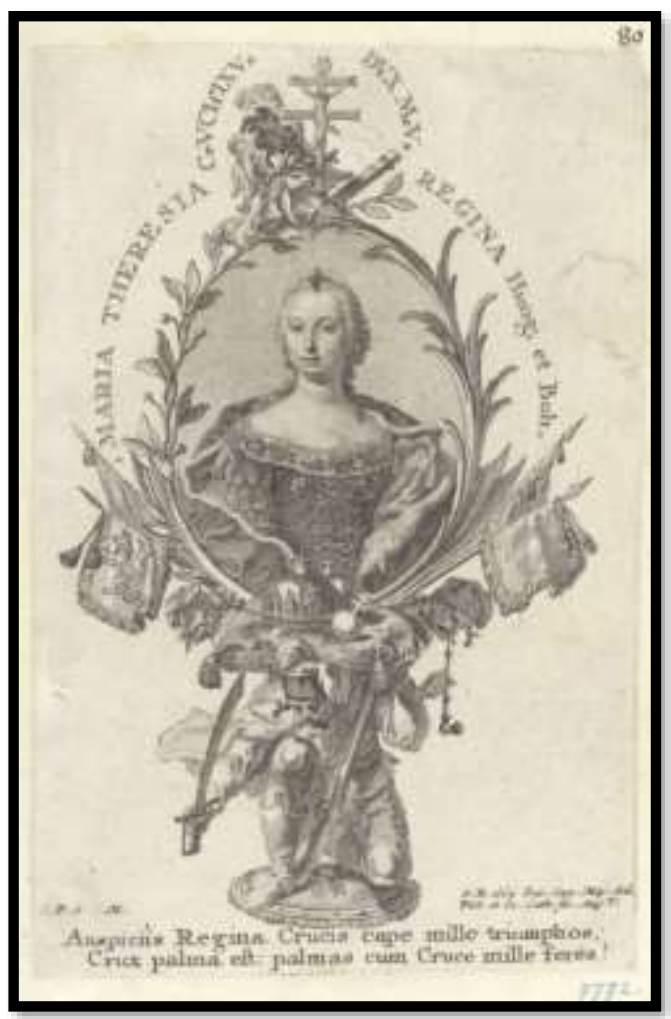

Resim 1111: Götz, Gottfried Bernhard. Kupferstichnach 1744. (Österreichische National Bibliothek PORT_00047710_01)

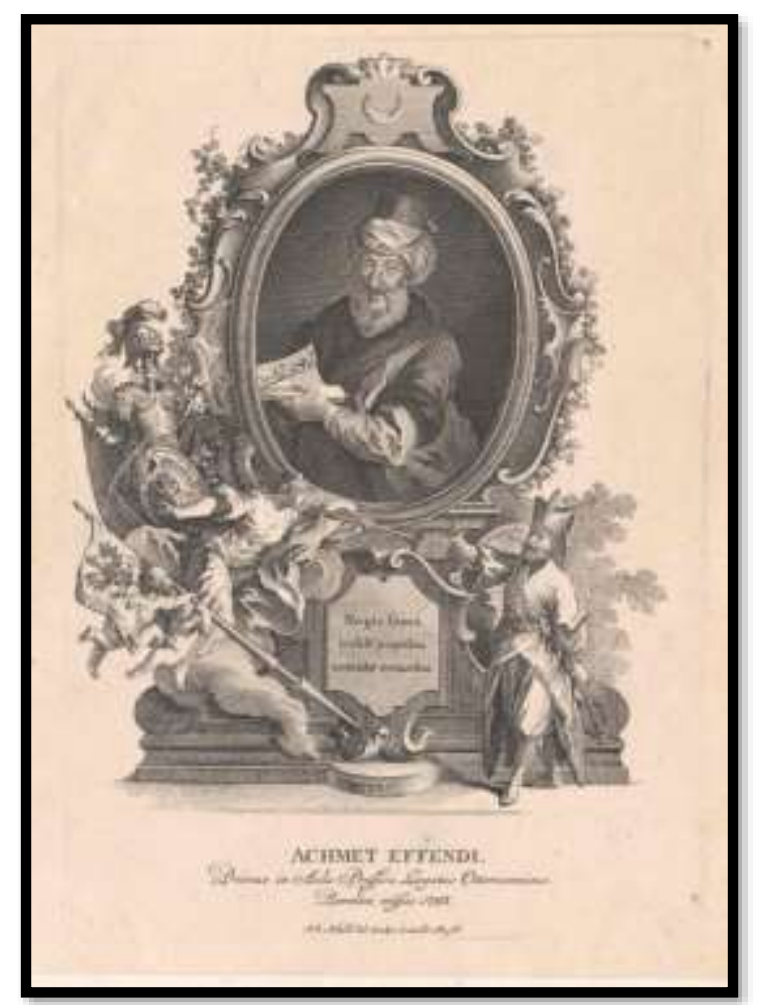

Resim 1212: Ahmet Resmi Efendi (http://www.bildarchivaustria.at/Preview/7920185.jpg)

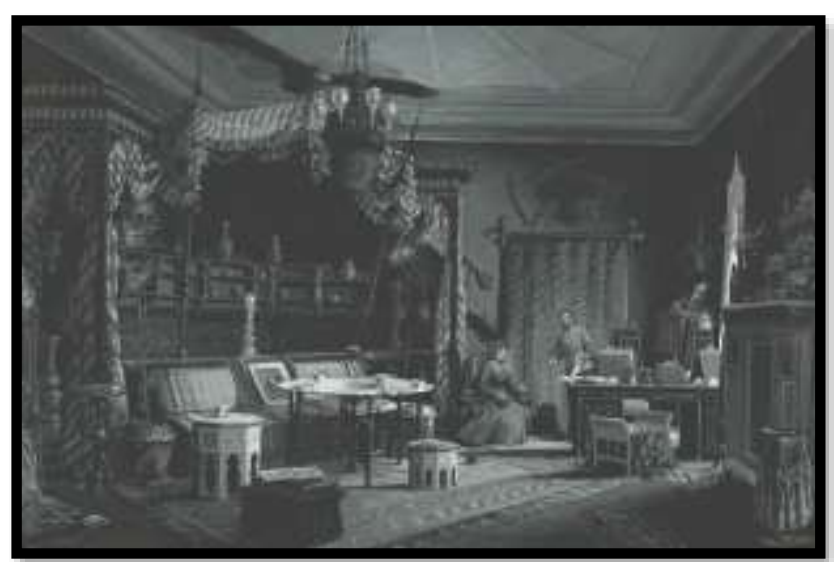

Resim 1313: Wilhelm Gause: „Türkisches Zimmer“ von Kronprinz Rudolf, um 1885, Gouache (Wien Museum) 